\title{
Two New Species of Nanuza (Velloziaceae) from Brazil
}

\author{
Ruy José Válka Alves \\ Departamento de Botânica, Herbário, Museu Nacional, Quinta da Boa Vista s.n., \\ São Cristóvão, Rio de Janeiro, RJ, Brazil
}

Abstract. Nanuza almeidae Alves and N. luetzelburgii Alves are described as new species of the previously monotypic Nanuza L. B. Smith \& Ayensu (Velloziaceae). Nanuza almeidae is distinguished from Nanuza plicata and $N$. luetzelburgii mainly by leaf blades basally narrowed into a pseudopetiole, linear-lanceolate tepals, triangular filaments with a flattened base, and presence of labdane-type diterpenes. Nanuza luetzelburgii is distinguished from both other species by rounded edges on the trigonous caudex, lamina with furrows with abundant, sturdy hairs, vestigial adaxial furrows, and serrulate sheath margins, lacking the filaments typical of the closely related $N$. plicata and $N$. almeidae, and by presence of heptadecenic acid. Xerophytolic acid was found in Nanuza plicata but not in both new species.

Resumo. Nanuza almeidae Alves e N. luetzelburgii Alves são descritas como espécies novas do gênero até então considerado monotípico, com apenas Nanuza plicata (Martius) L. B. Smith \& Ayensu (Velloziaceae). Nanuza almeidae se distingue de Nanuza plicata e $N$. luetzelburgii pelas tépalas linear-lanceoladas, limbo foliar na base estreitado em pseudopecíolo, mais largo e curto, adaxialmente glabrescente, filetes triangulares com base achatada e pela presença de diterpenos do tipo labdano. $\mathrm{Na}$ nuza luetzelburgii se distingue de $N$. plicata e $N$. almeidae pelas margens arredondadas do caudex trígono, preenchimento dos sulcos no limbo por abundantes pêlos rígidos, sulcos vestigiais na face adaxial, bainhas foliares com margens serreadas, sem as cerdas características de $N$. plicata e $N$. almeidae, bem como pela presença de ácido heptadecênico. Nanuza plicata se distingue das espécies novas pela presença de ácido xerofitólico.

Key words: Brazil, heptadecenic acid, leaf anatomy, Nanuza, tetracosanoic acid, Velloziaceae.

The Velloziaceae are a predominantly Neotropical family with a major center of diversity in Brazil's savannic vegetation (campo rupestre, cerrado, and caatinga). Many species are known only from their holotypes, duplicates are rare in herbaria, and many populations are narrowly endemic. A few spe- cies, such as Nanuza plicata, are apparently more widespread, occurring in several populations dispersed as a mosaic throughout their ranges. Though the populations of Nanuza are reported by some collectors as dense and common, the genus is poorly represented in herbaria, with the exception of SPF (over 50 specimens) and RB (ca. 20). The material of Nanuza sent by VIES (Herbario, Museu de Biologia Mello Leitâo, Santa Teresa, State of Espírito Santo) got lost in the mail during a flood, and no material (even under earlier synonyms) was located in GUA and HB.

The plicate leaves and trigonous caudex led Martius to describe Vellozia plicata (Martius, 1823) based on a plant he had collected in 1819 in Bahia. The species was subsequently transferred to Xerophyta by Sprengel (1827). A specimen collected in 1820 by Pohl in Minas Gerais was described as Vellozia triquetra Pohl (1827). Baker (1875) transferred Pohl's species to Xerophyta. The genus $\mathrm{Na}$ nuza was segregated from Vellozia Vandelli by Smith and Ayensu (1976), based on Vellozia plicata Martius (Martius, 1823). Smith and Ayensu based the new genus on plicate leaves with more deeply furrowed adaxial surfaces, trigonous caudex, and pollen dispersed in single grains, as opposed to Vellozia, which is characterized by terete leaves with furrows restricted to the abaxial surface and pollen in tetrads. The originally proposed differential characters still hold true for Nanuza as circumscribed here, with the exception of the relative depth of the furrows on the lamina, which are deeper on the abaxial side in $N$. luetzelburgii and $N$. almeidae.

A further distinctive character of Nanuza is the neatly tristichous leaf set (it is spiral in Vellozia). Though Vellozia candida Mikan has a slightly trigonous stem (Alves, 1994) hidden by a layer of sheaths forming a cylindrical caudex, and tristichous leaf rosettes, the clearly trigonous caudex distinctive of Nanuza conceals a cylindrical stem. A distinct pseudopetiole is present in Nanuza almeidae, and I have not found a reference to one in other Velloziaceae. Characters such as leaf indument, anatomy, and chemical constituents of epi- 
cuticular wax are believed to vary more in widespread species of Velloziaceae (Mello-Silva, 1990a, 1995b, 2000), although it seems early to consider this a rule. Chemical characters were found useful in delimitation of taxa (genera) by Salatino et al. (1989).

A recent phylogenetic study using chloroplast DNA (Salatino, 1999) supports the distinct position of Nanuza, still considering it a monotypic genus of Nanuza plicata (Martius) L. B. Smith \& Ayensu. Though collections are relatively infrequent, the studied material indicates that the variability in Nanuza can be partly accounted for by segregation of two species herein described as new, in which morphological, anatomical, and chemical differences are consistent with known geographical distribution. It is probable that, with more collections, additional species will be described from among the specimens left for now within Nanuza plicata.

The leaves of all species known so far are conduplicate-plicate and not simply plicate as stated in the description of the genus by Smith and Ayensu (1976). Furthermore, the furrows resulting from the plication in the lamina of all examined Nanuza plicata are deeper on the abaxial side, and not the adaxial as postulated by Smith and Ayensu (1976). This is also true for Nanuza almeidae, while the inverse occurs in N. luetzelburgii. The plication is most evident in dried leaves of $N$. plicata (Fig. $1 \mathrm{M}, \mathrm{N})$, and least perceptible in $N$. luetzelburgii (Fig. 1K, L). The leaf blades vary in dimensions, indument, and presence of a pseudopetiole. Leaf sheaths can have filamentous (Nanuza plicata and $N$. almeidae) or serrulate ( $N$. luetzelburgii) margins.

Flowers are known from a single specimen of both Nanuza almeidae and $N$. luetzelburgii and from less than $20 \%$ of the $N$. plicata vouchers in the consulted herbaria. All species typically have flowers with white tepals, though purple stripes were reported in buds of one Nanuza plicata population (G. E. Valente 148 \& A. Azevedo, SPF). An apical excavation was found in the hypanthium of all examined herbarium specimens of both new species, though Mello-Silva (1995a) observed a hypanthium entirely filled by the ovary on material from Pico das Almas in the State of Bahia.

The distinguishing characters of both new species herein are based essentially on the same morphological character set used to circumscribe other species of Velloziaceae in recent descriptions (Mello-Silva, 1990b, 1992). Anatomical differences in the transversal sections of leaf lamina and chemical constituents of selected specimens provided valuable additional characters for delimitation of the two new species and their distinction from Nanuza plicata.

Nanuza almeidae Alves, sp. nov. TYPE: Brazil. Rio de Janeiro: Município de Magé, Distrito de Piabetá, Fragoso/Tocaia, encosta rochosa de pedra próxima à base do Morro do Urubu, sobre a rocha em local ensolarado, $500 \mathrm{~m} \mathrm{s.} \mathrm{m.,}$ tépalas brancas, 12 Nov. 2000 (fl, fr), Paulo Roberto Almeida de Jesus s.n. (holotype, R). Figure 1A-J.

Haec species N. plicata (Martius) L. B. Smith \& Ayensu, tepalis lineari-lanceolatis, filamentis triangularibus basibus applanatis, foliis latioribus, adaxialiter nervis ecristatis ad basim in pseudopetiolum angustatis atque seminum testa profunde foveolata statim diagnoscitur.

Heliophyllous shrubs up to $150 \mathrm{~cm}$ tall; caudex basally cylindric, thickened by adventive root penetration, branching along the entire length, upper half and branches trigonous with rounded wedges, consisting externally of 3 series of leaf sheaths and ending in tristichous, apical leaf rosettes. Apical leaves in each rosette up to twice the size of those at the base; leaves deciduous, light green, glabrescent, parchment-like; lamina linear-lanceolate, 8$9 \times 90-95 \mathrm{~mm}$, conduplicate-plicate, abaxial furrows slightly deeper than adaxial, margins serrulate with the teeth curved toward the apex, base narrowed to $1-1.5 \mathrm{~mm}$ wide, conduplicate, with a curved pseudopetiole furrowed only on the abaxial side; leaf sheaths triangular, conduplicate, $20 \mathrm{~mm}$ long, base (when flattened) $5 \mathrm{~mm}$ wide, margins of apical half emitting long, vinaceous fibers that interlace with those of adjacent sheaths; inflorescence terminal, subtended by 2 linear-triangular, basally sheathing bracts equaling the tepals and later, by elongation, the apex of the capsule; flower single in each rosette; pedicel glabrous, trigonous, 1.5-2 $\times$ $80 \mathrm{~mm}$; tepals 6, white, membranous, glabrous, linear-lanceolate, in 2 whorls, subequal, with acrodromous venation; outer tepals $38 \times 7 \mathrm{~mm}$ wide, with conspicuous midribs; inner tepals more delicate, $37 \times 10 \mathrm{~mm}$ wide; hypanthium $34 \mathrm{~mm}$ long, glabrous, conspicuously trigonous, basally $2 \mathrm{~mm}$ broad and hardly delimited from the pedicel, apically $5 \mathrm{~mm}$ diam., with a $2 \mathrm{~mm}$ depression; ovary, except for the apical excavation, filling $90 \%$ of the hypanthium; style trigonous, in the center of the depression, $1 \times 35 \mathrm{~mm}$; stigma capitate, $3 \times 4$ $\mathrm{mm}$, lobes fleshy; stamens 6, $20 \mathrm{~mm}$ long; filaments triangular, $3 \mathrm{~mm}$ long, basally $1 \mathrm{~mm}$ wide, inserted atop the hypanthium margins; anthers $17 \mathrm{~mm}$ long, basally auriculate, thecae subequal; pollen dispersed in monosulcate monads, $35.5 \times 25.7 \mu \mathrm{m}$, with the aperture at the distal pole, with reticulate 

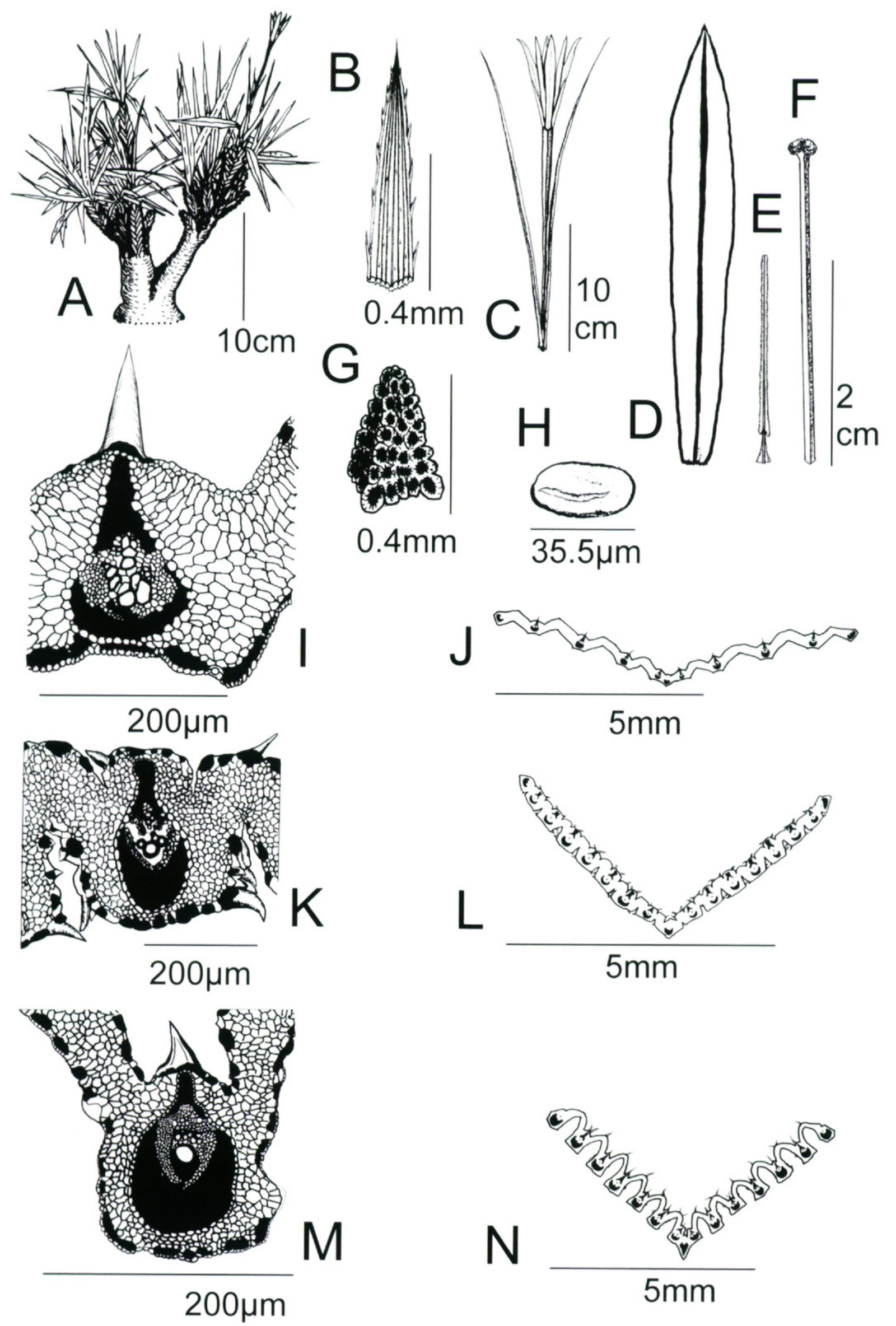

Figure 1. A-J. Nanuza almeidae Alves drawn from the holotype Paulo Roberto Almeida de Jesus s.n. (R). - A. Habit. -B. Leaf apex. - C. Flower subtended by 2 bracts. - D. Tepal from outer whorl. - E. Stamen. -F. Style. - G. Seed.-H. Pollen monad. - I. Transverse section of vascular bundle topped by sturdy hair. —J. Median transverse 
exine; capsule $45 \mathrm{~mm}$ long, $8 \mathrm{~mm}$ diam., longitudinally dehiscent from apex to $1 / 2$ length, externally sulcate, similar to, though smaller, than that on examined specimens of $N$. plicata; seeds pale brown, pyramidal, testa reticulate-foveolate, slightly translucent.

Transversal section of lamina. Vascular bundles 11 ; midvein and the 2 vicinal vascular bundles circular, with sclerenchyma girders only abaxial, the 4 subsequent pairs of bundles pear-shaped, with conspicuous abaxial $\mathrm{U}$-shaped and adaxial sagitttate girders; marginal trace with abaxial girder large and asymmetrical, adaxial girder lacking or vestigial; mesophyll adaxially with palisade grading into spongy tissue. Bundle sheath distinct, in contact with abaxial and adaxial epidermis.

The type specimen was collected on a granitic inselberg known as Morro do Urubu emerging from degraded Atlantic rainforest in the state of Rio de Janeiro, from the municipality of the type citation.

Nanuza almeidae is most easily distinguished in herbarium material by leaf blades with a distinct pseudopetiole, lamina wider than $1 \mathrm{~cm}$ lacking serrulate crests on the adaxial surface, and by linearlanceolate tepals. In contrast, broadly lanceolate tepals are shared by Nanuza almeidae and N. plicata, and the latter has serrulate crests. The triangular filaments with a flattened base and seeds with deeper pits in the reticulate seed coat distinguish it further from N. plicata. The specific epithet refers to the collector of the holotype, Paulo Roberto Almeida de Jesus, an enthusiastic potential field naturalist who frequently surprises us in the herbarium bringing large bags filled with curious plants, arthropods, mollusks, and minerals, which we distribute to specialists and collections. His first collection, now cultivated at our institution, inspired this study and part became the holotype of Nanuza almeidae.

Paratypes. BRAZIL. Bahia: Pedra Azul, 4 km da cidade na estrada MG-105 para Jequitinhonha, Inselberg à beira da estrada, R. M. Silva 440 et al. (SPF). Espírito Santo: Vale do Rio Pancas, cultivated in Pedra de Guaratiba, Rio de Janeiro by Burle Marx, N. L. Menezes s.n. (SPF); Colatina, BR-259 a 17 km de Colatina para João Neiva, Grande afloramento rochoso, 13 Jan. 1985, J. R. Pirani \& D. Zappi 1117 (SPF); Vitória, Guajurá, Praia do Canto, A. G. Silva 463 (R); Vitória, Morro do Guajurá, Praia do Canto, 27 Aug. 1984, A. G. Silva 449 (RB). Rio de Janeiro: Mun. Magé, Distrito de Piabetá, Fragoso/Tocaia, base do Morro do Urubu, 500 m s. m., 20 Nov. 2000 (f), Paulo Roberto Almeida de Jesus s.n. (R); s.l., s.d., Carlos Viana Freire s.n. (R-50224).

Nanuza luetzelburgii Alves, sp. nov. TYPE: Brazil. Pernambuco: Serra Talhada, Serra da Carnaubeira, Serrote Redondo, Lagedo no Topo da Serra, arbusto 50-80 cm, 22 May 1971 (fr), E. P. Heringer 826, D. Andrade Lima, J. de P. L. Sobrinho \& A. C. Sarmento (holotype, R; isotype, RB). Figure 1K, L.

Haec species caudice obscure triquetro aristis rotundatis et foliorum vagina serrulata esetosa atque laminae sulcis utrinque trichomatibus brevibus rigidis numerosis instructis abaxialibus, quam adaxialibus 4-plo profundioribus statim distinguitur.

Shrubs to $80 \mathrm{~cm}$ tall; caudex branches trigonous with rounded edges, 12-15 mm diam., densely packed with 3 series of leaf sheaths with serrulate margins; leaves rigid; lamina linear-lanceolate, 3$5 \mathrm{~mm}$ wide, 14-25 cm long, without pseudopetiole, conduplicate, conspicuously plicate (in dry material plication barely detectable and lamina conduplicate along midrib, then bent back outward along 4th rib), in smaller scale vestigially plicate along all ribs; abaxial and adaxial furrows internally with abundant short and sturdy hairs; flowers solitary; tepals lanceolate-elliptic, $7 \mathrm{~mm}$ wide, $27 \mathrm{~mm}$ long, white [!L. Emperaire s.n., SPF]; pedicel $0.2 \mathrm{~cm}$ wide, $11 \mathrm{~cm}$ long, grading into a $70 \mathrm{~mm}$ long, 3 $\mathrm{mm}$ wide trigonous ovary; stamens 6 , erect, yellow; style with stigma exceeds stamens by $5 \mathrm{~mm}$. Capsule (A. Fernandes s.n., SPF) dry, dehiscent, clavate, basal half $3-7 \mathrm{~cm}$ long, to $2-3 \mathrm{~mm}$ diam., the apical half thickens abruptly to 8-9 $\mathrm{mm}$ diam.; surface sulcate-striate as in both other species.

Transversal section of lamina. Spongy tissue filling almost the entire mesophyll; midvein and marginal veins with only abaxial sclerenchyma girder, the remaining 7 pairs with both; the adaxial girder with clavate apex and Y-shaped base. Adaxial furrows vestigial, abaxial four times deeper; midvein distinct with only abaxial sclerenchyma bundle; mesophyll with spongy tissue; bundle sheath distinct, not in contact with either epidermis; cuticle layer discontinuous.

Lamina of material from Pernambuco (E. P. Her-

$\leftarrow$

section of lamina. K, L: N. luetzelburgii Alves drawn from E. P. Heringer 826, D. Andrade Lima, J. de P. L. Sobrinho \& A. C. Sarmento (holotype, R; isotype, RB). - K. Transverse section of vascular bundle; note hairs in abaxial furrows and on adaxial surface. - L. Median transverse section of lamina. M, N. N. plicata. - M. Transverse section of vascular bundle. - N. Median transverse section of lamina with bundle topped by sturdy hair. In I, K, and M, sclerenchyma and cuticle are in black. 
inger 826, D. Andrade Lima, J. de P. L. Sobrinho \& A. C. Sarmento, R, RB) with 17 vascular bundles and adaxial cuticle $2-3$ cells thick; material from Piauí (L. Emperaire 715, IPA) has 13 bundles and a thicker cuticle (4-5 cells). This seems related to differences in annual rainfall (ca. $500 \mathrm{~mm}$ in Pernambuco and $<300 \mathrm{~mm}$ in Piauí).

The specific epithet refers to the first collector, Philip von Lützelburg, a naturalist and important plant collector in northeastern Brazil.

Paratypes. BRAZIL. Pernambuco: Serra Talhada, Serra da Carnaubeira, Serrote Redondo, 22 May 1971, E. P. Heringer, D. Andrade Lima, J. de P. L. Sobrinho \& A. C. Sarmento s.n. (R, RB); Petrolina, July 1974, D. Andrade Lima s.n. (SPF); Flores, Serra do Cruzeiro na estrada Triunfo-Sítio dos Nunes, 28 Mar. 1970, D. Andrade-Lima 70-5848 (IPA). Piaú: São Raimundo Nonato, Caldeirão dos Rodrigues, 7 Jan. 1985, Laure Emperaire s.n. [fl], Ex Herbário da Missão Franco-Brasileira no Piauí (SPF); Serra da Capivara, 1979, Laure Emperaire 715 [fr] (IPA, RB); Serra dos Ca_?, 6 July 1912, Lützelburg 1210 (RB); Serra da Capivara, 1979, Laure Emperaire 494 (IPA); Guaribas, Parque Nacional da Serra das Confusões, Gruta do Boi, ca. de 20 km de Caracol. 1-15 Oct. 2000 [st], Percequillo, A. R. \& Rodrigues, M. T. U. s.n. (SPF); Caracol, Serra das Confusões, Jorge, A. s.n. [st] (SPF), A. Fernandes s.n. [fr] (SPF); Município São Raimundo Nonato, Margem direita da Estrada Canto do Buriti, S. Raimundo Nonato, 13 Oct. 1999, França, A. R. et al. s.n. [st], Ex Herbário TEGB (SPF); Piauí?: Nordeste, Excursão com Bigarela, Aug. 1972, D. Andrade-Lima 72-6958 (IPA).

Gas chromatographic analysis coupled with mass spectrometry of the crude extract obtained in dichloromethane was conducted on samples of all three species. Nanuza almeidae revealed diterpenic skeletons of the labdane type not found in the other species and tetracosanoic acid $\left\{\mathrm{C}_{25} \mathrm{H}_{50} \mathrm{O}_{2}\right.$, molecular mass $=382\}$; Almeida s.n. (R). Nanuza luetzelburgii revealed 8-heptadecenic acid $\left\{\mathrm{C}_{18} \mathrm{H}_{34} \mathrm{O}_{2}\right.$, molecular mass $=282\}$; Heringer 826 et al., $R$ Laure Emperaire 715 (IPA). No long-chain acids were found in $N$. plicata, which revealed only a mixture of carbohydrates with chain lengths of 12, 22, 27 . and 35 carbons in a recent sample (Riehl s.n., R), from the same population in Nova Friburgo, Rio de Janeiro, from which Riehl et al. (2000) had described xerophytolic acid.

As all species of Nanuza are insufficiently represented in collections, their distribution remains insufficiently known. At present, it seems that $\mathrm{Na}$ nuza almeidae occurs on gneiss-granitic inselbergs composing mountain chains of the first belt parallel to the coast, in the states of Bahia, Espírito Santo, and Rio de Janeiro. Nanuza luetzelburgii is known only from basaltic outcrops in the caatinga (dry savanna) of Pernambuco and Piauí in northeastern Brazil. Nanuza plicata has a broader range, growing on rock outcrops of various types throughout the Espinhaço and Chapada Diamantina mountain chains.

Color images complementing this article will be available at the internet address 〈http://acd.ufrj.br/ $\sim$ mndb/nanuza.html $\rangle$ immediately after printing.

\section{Key to THE SPECIES OF NANUZA}

1a. Caudex distinctly trigonous to triquetrous, with sharp edges; abaxial furrows of lamina well developed, without hairs; leaf sheath margins emitting long fibers that interlace on the caudex.

2a. Lamina linear to lanceolate, without pseudopetiole, tepals elliptic ......... plicata

2b. Lamina with distinct pseudopetiole, adaxially glabrescent, tepals linear-lanceolate

N. almeidae

1b. Caudex obscurely trigonous with rounded edges, abaxial furrows of lamina with abundant scabrous hairs; adaxial furrows half the depth of abaxial; leaf sheath margins serrulate, without fibers

N. luetzelburgii

Selected additional examined material of N. plicata. BRAZIL. Bahia: Mun. Água Quente, Pico das Almas, Vertente oeste, entre Paramirim das Crioulas e a face $\mathrm{NNW}$ do Pico, $13^{\circ} 31^{\prime} \mathrm{S}, 42^{\circ} 00^{\prime} \mathrm{W}, 1250 \mathrm{~m}$ s. m., R. M. Harley 27535 (SPF); Mun. Bom Jesus da Lapa, Caatinga sobre afloramentos (lagedos) rochosos, 14 Feb. 1991, G. M. Hatschbach 55144 \& O. S. Ribas (SPF); Monte Santo, 3 Oct. 1972, D. Andrade Lima s.n. (SPF); Monte Santo [localidade típica], 4 Feb. 1972, D. Andrade Lima s.n. (RB); Mun. Gentio do Ouro, 27 Nov. 1992, M. M. Arbo, R. M. Silva \& João Vicente 5337 (RB); Mun. Barra da Estiva, $16 \mathrm{~km}$ NE de Barra da Estiva, $790 \mathrm{~m} \mathrm{~s}$. m., 24 Nov. 1992, M. M. Arbo, R. M. Silva \& João Vicente 802 (RB); Mun. Santo Inácio, Serra do Açuruá, Arredores da cidade, 26 Oct. 1970, D. Andrade-Lima 70-6150 (IPA); Mun. Acobina, Campo Formoso, 21 July 1978, D. Andrade-Lima 78-8577 (IPA). Espírito Santo: Mun. Colatina, Angelo Freschiani, ca. $3 \mathrm{~km}$ após Ponte do Pancas, ca. $200 \mathrm{~m} \mathrm{~s}$. m., veg. campestre em afloramento gneissico, $H$. Q. Boudet Fernandes 2684 et al. (SPF); Mun. Colatina, 15 km N de Colatina, 4 Dec. 1994, J. R. Pirani, M. A. G. Magenta \& A. A. Conceição s.n. (RB); Colatina, Rodovia ES-080, ca. 15 km a Norte de Colatina, 4 Dec. 1994, J. R. Pirani et al. s.n. (SPF). Minas Gerais: Juíz de Fora, Linhares, Pedreira Santo Cristo, 15 May 1996, A. N. Caiafa \& G. L. G. Soares s.n. (SPF); $10 \mathrm{~km}$ a Sul de Medina, rodovia BR-116, 20 Nov. 1985, G. Hatschbach 50013 \& J. M. Silva (SPF); Mun. Itinga, $5 \mathrm{~km}$ de Itinga, R. M. Silva 427 et al. (RB, SPF); Mun. Itinga, Santana do Araçuari, 28 Aug. 1982, L. G. Mautone, E. F. Guimarães \& C. T. Rizzini s.n. (RB); Parque Estadual da Serra do Brigadeiro, Serra da Araponga, Fazenda Neblina, Próximo ao laboratório de Campo, trilha subindo morro, 30 Sep. 1995, J. A. Lombardi 983 (SPF); Mun. Mantena, Rio Preto, Fazenda Boa Vista do Sr. Antonio Ferreira Valente, 14 Oct. 1995. G. E. Valente 148 \& A. Azevedo (SPF), 14 Oct. 1995, G. E. Valente 147 \& A. Azevedo (SPF); Pedra Azul, $15 \mathrm{~km}$ da cidade, V. C. Souza 5193 et al. (SPF); Mun. Carlos Chagas, Rodovia BR418, Rio Quegeme, paredões rochosos, G. Hatschbach 47086 (SPF); Águas Vermelhas, próximo ao Curral de Dentro, margem da Rodovia 251, 15 Aug. 1974. D. Andrade Lima s.n. (SPF); Mun. Varzelândia, Serra da 
Caatinga, sobre a Lapa do Varal, 1 Feb. 1985, J. G. da Silva 1069 \& M. Menezes (R); Mun. Varzelândia, Barreirinho, 7 Feb. 1985, J. G. da Silva 1143 \& M. Menezes (R); Serra do Torreão, July 1897, F. Brandão s.n. (RB). Rio de Janeiro: Mun. Petrópolis, Araras, Malta, 8 Nov. 1968, P. I. S. Braga 1354 (RB); Mun. Petrópolis, Pedro do Rio, Secretário, Nascente do Rio Capim Roxo, 7 Dec. 1986, G. Martinelli 11985 \& C. Alvim (RB).

Acknowledgments. I thank colleague Jorge Fontella Pereira for the Latin diagnoses, Vania Gonçalves Esteves and Claudia Barbieri Ferreira Mendonça for aid with the pollen description and image, Jenilce R. Martins, Claudia M. Rezende, and Angelo C. Pinto for aid with the chemical analyses and the curators of GUA, HB, IPA, R, RB, SPF, and VIES for support.

\section{Literature Cited}

Alves, R. J. V. 1994. Morphological age determination \& longevity in some Vellozia populations in Brazil. Folia Geobot. Phytotax. 29: 55-59.

Baker, J. G. 1875. Synopsis of the African species of Xerophyta. J. Bot. 13: 236.

Martius, C. F. P. von. 1823. Velloziaceae. In: Nov. Gen. Sp. Pl. 1: 16, t.9.

Mello-Silva, R. de. 1990a. Morphological and anatomical differentiation of Vellozia hirsuta populations (Velloziaceae). Pl. Syst. Evol. 173: 197-208. 1990b. A new species of Vellozia from the Espinhaço Range, Brazil, with some considerations on the section Xerophytoides. Kew Bull. 46: 321-326.

1992. Three new species of Vellozia from Pico das Almas, Bahia, Brazil, with an account of their leaf anatomy. Kew Bull. 48: 1-8.

. 1995a. Velloziaceae. In: B. L. Stannard (editor), Flora of the Pico das Almas, Chapada Diamantina, Bahia, Brazil. Royal Botanic Gardens, Kew.

. 1995b. Aspectos taxonômicos, biogeográficos, morfológicos e biológicos das Velloziaceae de Grão-Mogol, Minas Gerais, Brasil. Bol. Bot. Univ. São Paulo 14: $49-79$.

2000. Partial cladistic analysis of Vellozia and characters for the phylogeny of Velloziaceae. In: K. A. Wilson \& D. A. Morrison (editors), Monocots: Systematics and Evolution. CSIRO, Melbourne. [Abstract.]

Pohl, J. E. 1827. Velloziaceae. In: Pl. Bras. 1: 129.

Riehl, C. A. S., A. C. Pinto \& C. R. Kaiser. 2000. Isolation and structural determination of xerophytolic acid, a novel 3-geranyl-4-hydroxybenzoate derivative from Xerophyta plicata. Spectroscopy Lett. 33(5): 643-651.

Salatino, A. 1999. Main results from trnL-F sequencing of Velloziaceae and allied taxa. Anais Acad. Brasil. Ci. 71: 203-206.

Salatino, M. L. F., A. Salatino, N. L. de Menezes \& R. de Mello Silva. 1989. Alkanes of foliar epicuticular waxes of Velloziaceae. Phytochemistry 28: 1105-1114.

Smith, L. B. \& E. S. Ayensu. 1976. A revision of American Velloziaceae. Smithsonian Contr. Bot. 30: 1-172.

Sprengel, K. P. J. 1827. Velloziaceae. In: Syst. Veg. 4(2): 137. 

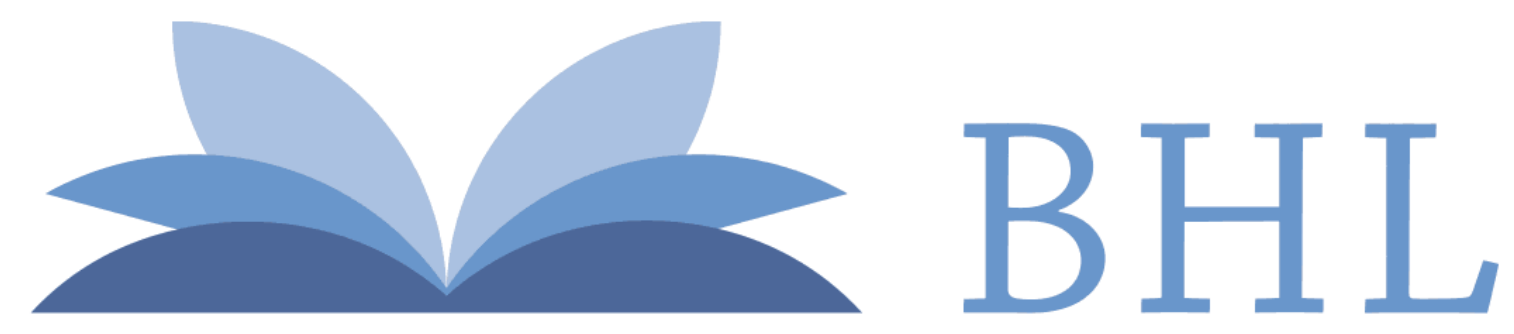

\section{Biodiversity Heritage Library}

Alves, Ruy José Válka. 2002. "Two new species of Nanuza (Velloziaceae) from Brazil." Novon a journal of botanical nomenclature from the Missouri Botanical Garden 12, 12-17.

View This Item Online: https://www.biodiversitylibrary.org/item/14672

Permalink: https://www.biodiversitylibrary.org/partpdf/36466

\section{Holding Institution}

Missouri Botanical Garden, Peter H. Raven Library

\section{Sponsored by}

Missouri Botanical Garden

\section{Copyright \& Reuse}

Copyright Status: In copyright. Digitized with the permission of the rights holder.

License: http://creativecommons.org/licenses/by-nc-sa/3.0/

Rights: https://biodiversitylibrary.org/permissions

This document was created from content at the Biodiversity Heritage Library, the world's largest open access digital library for biodiversity literature and archives. Visit BHL at https://www.biodiversitylibrary.org. 